ISSN 0258-7122

Bangladesh J. Agril. Res. 38(3): 435-445, September 2013

\title{
EFFECT OF SEED RATE AND SOWING METHOD ON FOLIAGE PRODUCTION OF DIFFERENT GENOTYPES OF CORIANDER \\ (Coriandrum sativum $\mathbf{L}$.)*
}

\author{
M. MONIRUZZAMAN ${ }^{1}$, M. M. RAHMAN ${ }^{2}$, M. M. HOSSAIN ${ }^{3}$ \\ A. J. M. SIRAJUL KARIM ${ }^{4}$ AND Q. A. KHALIQ ${ }^{5}$
}

\begin{abstract}
A field experiment on coriander (Coriandrum sativum L.) was conducted at Bangabandhu Sheikh Mujibur Rahman Agricultural University, Gazipur during February 2009 to April 2009 to find out the optimum seed rate in relation to sowing methods for maximizing foliage yield of coriander. Four genotypes (CS001, CS002, CS003 and CS008) and three sowing methods (continuous line sowing spaced at $10 \mathrm{~cm}, 20 \mathrm{~cm}$ and broadcast method) and three levels of seed rate $(30,40$ and $50 \mathrm{~kg} / \mathrm{ha})$ were used as treatment variables.. The result showed that genotype CS003 singly gave the maximum plant height, number of leaves/plant, single plant weight and plant weight $/ \mathrm{m}^{2}$ and thus gave the highest foliage yield/ha. Line sowing $(10 \mathrm{~cm})$, broadcast method with seed rate@ 50 $\mathrm{kg} / \mathrm{ha}$ independently produced the maximum foliage weight $/ \mathrm{m}^{2}$ and foliage yield/ha. Line sowing $(10 \mathrm{~cm})$ with $50 \mathrm{~kg} / \mathrm{ha}$ seed rate produced the highest foliage yield in case of CS001, CS002 and CS003 genotypes, which was closely followed by broadcast method and the same seed rate. But line sowing $(10 \mathrm{~cm})$ as well as broadcast method coupled with $40 \mathrm{~kg} / \mathrm{ha}$ seed rate gave better foliage yield in genotype CSO08.
\end{abstract}

Keywords: Coriander, Coriandrum sativum L., sowing method, seed rate, and green foliage.

\section{Introduction}

Coriander (Coriandrum sativum L.) is an important spice crop grown mainly in rabi season of Bangladesh. It is an aromatic culinary herb belonging to the family Apiaceae. It is grown for its aromatic and fragrant seeds and leaves. The entire plant of young coriander is used as appetizer in preparing fresh chutneys and sauces. Leaves are used to flavour food, curries, soups, fish sauce, cream sauce for chicken, tomato soup, pickling sausages, bakery preparations, liqueurs, gins and meat (Janardhonan and Thoppil, 2004).

It is well known that establishment of an optimum plant density per unit area is one of the important factors contributing to the increased productivity of a

\footnotetext{
${ }^{1}$ Senior Scientific Officer, HRC, Bangladesh Agricultural Research Institute (BARI), Gazipur 1701, ${ }^{2 \& 3}$ Professor, Dept. of Horticulture, Bangabandhu Sheikh Mujibur Rahman Agricultural University (BSMRAU), Salna, Gazipur-1706, ${ }^{4}$ Professor, Dept. of Soil Science, BSMRAU, Salna, Gazipur-1706, ${ }^{5}$ Professor, Dept. of Agronomy, BSMRAU, Salna, Gazipur-1706, Bangladesh.

*This is a part of Ph.D dessertation.
} 
crop. Among the factors which can increase the crop yield on per unit area basis, seed rate and sowing methods are considered to be the most important (Mozumder et al., 2010). The foliage yield of coriander largely depends plants per unit area, plant height and leaves per plant. More the number of coriander plants per unit area the more is in the yield of foliage. Besides, higher plant population may compensate the lower individual plant weight which is determined by plant height and leaves per plant. Maximum genetic potential of the coriander cannot be harvested without ensuring the proper sowing method. Ayub et al. (2008) reported that continuous line sowing gave higher yield of fennel compared to broadcast though higher plant density was observed in broadcast method. Gimson (1985) reported that a sowing rate of $50-55 \mathrm{~kg} / \mathrm{ha}$ gives the highest yields of foliage in coriander. In view of the above facts the experiment was, therefore, undertaken to find out an appropriate seed rate in relation to sowing methods for higher foliage yield of coriander.

\section{Materials and Method}

The experiment was conducted at Bangabandhu Sheikh Mujibur Rahman Agricultural University (BSMRAU), Gazipur during February 2009 to April 2009. The initial soil samples of the experimental field were collected and analyzed following standard laboratory procedures and presented in Table 1 . The soil was slightly acidic (pH 6.2) having low organic matter content (1.96\%). The content of total $\mathrm{N}$ was very low. Available $\mathrm{P}, \mathrm{S}$ and exchangeable $\mathrm{K}, \mathrm{Ca}$ and $\mathrm{Mg}$ were also low. The climatic data of air temperature $\left({ }^{\circ} \mathrm{C}\right)$ and rainfall $(\mathrm{mm})$ during experimentation was given in Table 2. The four genotypes (CS001, CS002, CS003, and CS008) collected from Siddique Bazzar, Dhaka but the genotype CS008 was collected from Tangail district. These materials showed better performances in respect of foliage production in the earlier experiment. Four genotypes (CS001, CS002, CS003, and CS008), three sowing methods (continuous line sowing spaced at $10 \mathrm{~cm}, 20 \mathrm{~cm}$ and broadcast method) and three levels of seed rates $(30,40$ and $50 \mathrm{~kg} / \mathrm{ha})$ were used as experimental material. The experiment was laid out in a split-split plot design with three replications. Genotypes were assigned in the main plot, three sowing methods were placed in sub-plots and three seed rates in sub-sub plot. The unit plot size was $3 \mathrm{~m} \times 1 \mathrm{~m}$. The land was fertilized with 5 tons, cowdung, $40 \mathrm{~kg} \mathrm{~N}, 11 \mathrm{~kg} \mathrm{P}$, and $25 \mathrm{~kg} \mathrm{~K}$ per hectare. The entire amount of cowdung, phosphorus from TSP, and potassium from MoP and one- half of nitrogen from urea was applied during final land preparation. The rest of the nitrogen was top-dressed at 20 days after sowing. The seeds (fruits) were rubbed for separating the two mericarps (seeds) and were soaked in water for 24 hours to enhance germination. Seeds were also treated with Bavistin at the rate of $2 \mathrm{~g}$ per $\mathrm{kg}$ of seeds before sowing. The seeds of each genotype were sown maintaining experimental sowing methods and seed rate on 29 February 2009. The weeding was done after 20 days after sowing (DAS). 
Plant thinning was not done for the crop. For uniform germination water was given to the plots every three days by water can with fine mashed nozzle till germination. Besides, two irrigations were given to the crop at 25 and 32 days after sowing. Harvesting of plants was done by cutting just beneath the soil when few plants were seen to bolt depending upon the genotypes.

Data were collected from the inner rows of each plot to avoid the border effect. In each unit plot 10 plants were selected randomly for recording data on plant height $(\mathrm{cm})$ and yield attributes. Plot yield was converted to per hectare yield. The data were compiled properly and analyzed statistically and mean comparison was done following the Duncan's New Multiple Range Test (DMRT) at 5\% level of probability.

Table 1. Initial soil sample of the experimental field.

\begin{tabular}{lc|c|c}
\hline Chemical properties & Analytical value & Critical level & Optimum level \\
\hline Soil pH & 6.2 & - & - \\
Organic matter (\%) & 1.96 & - & - \\
Total N (\%) & 0.078 & 0.075 & 3.0 \\
Available P (ppm) & 30.74 & 14.0 & 60.0 \\
Exchangeable K (meq/100 g soil) & 0.37 & 0.2 & 1.5 \\
Exchangeable Ca (meq/100 g soil) & 5.37 & 2.0 & 18.0 \\
Exchangeable Mg(meq/100 g soil) & 1.66 & 0.8 & 9.0 \\
Available B (ppm) & 0.30 & 0.20 & 3.0 \\
Available S (ppm) & 13.5 & 14.0 & 60.0 \\
Available Zn (ppm) & 2.55 & 2.0 & 12.0 \\
Available Cu (ppm) & 6.8 & 1.0 & 10.0 \\
CEC & 15.48 & - & - \\
\hline
\end{tabular}

Table 2. Air temperature and rainfall during February 2009 to April 2009.

\begin{tabular}{l|c|c|c|c|c}
\hline \multirow{2}{*}{ Months } & Days & \multicolumn{3}{|c|}{ Air temperature $\left({ }^{\circ} \mathrm{C}\right)$} & \multirow{2}{*}{ Rainfall (mm) } \\
\cline { 3 - 5 } & & Max. & Min. & Mean & \\
\hline February & $1^{*}$ & 22.60 & 18.10 & 20.30 & 0.00 \\
& $2^{*}$ & 24.53 & 19.85 & 22.23 & 55.20 \\
\multirow{4}{*}{ March } & $3^{*}$ & 26.25 & 21.44 & 21.44 & 9.09 \\
& 1 & 28.40 & 23.80 & 26.10 & 14.30 \\
\multirow{3}{*}{ April } & 2 & 28.60 & 24.80 & 26.70 & 0.70 \\
& 3 & 29.36 & 25.18 & 27.23 & 2.92 \\
& 1 & 30.30 & 25.50 & 27.90 & 38.63 \\
& 2 & 31.95 & 26.95 & 29.45 & 0.00 \\
\hline
\end{tabular}

$1^{*}$ stands for the days 01 to $10 ; 2^{*}$ stands for the days 11 to 20 and $3^{*}$ stands for the days 21 to the rest.

Source: Weather Station, Dept. of Agricultural Engineering, BSMRAU, Salna, Gazipur. 


\section{Results and Discussion}

Performance of genotypes: The genotypes differed significantly from one another in all parameters studied (Table 3). The maximum plant height (24.77 $\mathrm{cm})$, leaves/plant $(7.31)$, and individual plant weight $(2.93 \mathrm{~g})$ were recorded in CS003 and the least from CS008 genotype. The genotype CS008 gave the highest number of plants $/ \mathrm{m}^{2}$ (526.6), while genotype CS002 produced the lowest number of plants $/ \mathrm{m}^{2}$ (431.0). The highest plant weight $/ \mathrm{m}^{2}(1.21 \mathrm{~kg})$ was found in CS003 and the lowest in CS008 $(0.44 \mathrm{~kg})$. The highest yield $(11.59 \mathrm{t} / \mathrm{ha})$ was recorded in CSOO3 and significantly out-yielded the other genotypes. The genotype CS001 produced $10.44 \mathrm{t} / \mathrm{ha}$ foliage followed by CS002 (9.12 t/ha). The genotype CS008 was the lower yielder $(4.39 \mathrm{t} / \mathrm{ha})($ Fig. $1 \mathrm{~A})$. The genotypes CS003, CS001 and CS002 gave 62, 58 and 52\% higher yield, respectively, than genotype CS008. The genotype CS003 gave 10 and $21.3 \%$ higher yield compared to CSO01 and CS002, respectively. The CSO03 was the best yielder genotype because it produced the maximum plant height, number of leaves/plant, and plant weight $/ \mathrm{m}^{2}$. The genotypic differences with regards to different parameters were due to their inherent capacity.

Effect of sowing method: Number of leaves/plant, single plant weight, plants $/ \mathrm{m}^{2}$, and yield were significantly influenced by sowing methods. Variation of sowing methods did not show significant effect in respect of plant height (Table 3). Closer spacing $(10 \mathrm{~cm})$ and broadcast method produced more leaves/plant than wider spacing $(20 \mathrm{~cm})$. Line sowing spaced at $10 \mathrm{~cm}$ gave the highest number of leaves/plant (6.73) while lowest in $20 \mathrm{~cm}$ line spacing. The maximum single plant weight was recorded from $10 \mathrm{~cm}$ spacing $(2.32 \mathrm{~g} / \mathrm{plant})$ but the least in $20 \mathrm{~cm}$ line sowing. In fact, less number of seeds was sown per single line in closer spacing $(10 \mathrm{~cm})$ and more seeds were sown per line in wider spacing $(20 \mathrm{~cm})$ because number of lines/rows in closer spacing was more than that in wider spacing.

The result is in partial agreement of Mozumder et al. (2010) who obtained the maximum plant weight in $10 \mathrm{~cm}$ spacing closely followed by broadcast method in another culinary herb, 'Bangladhonia' (Eryngium foetidum L).The broadcast method produced the highest number of plants $\left(511.4 / \mathrm{m}^{2}\right)$ while the lowest from $20 \mathrm{~cm}$ spacing $\left(439.5 / \mathrm{m}^{2}\right)$. This corroborates the result of Mozumder et al. (2010). The weight of plants $/ \mathrm{m}^{2}$ from the closer spacing $(1.01 \mathrm{~kg})$ and broadcast method $(0.99 \mathrm{~kg})$ were statistically identical.

The closer spacing gave maximum foliage yield $(9.78 \mathrm{t} / \mathrm{ha})$ and it was statistically similar to that of broadcast method $(9.51 \mathrm{t} / \mathrm{ha})$ and the wider spacing had minimum foliage yield (7.36 t/ha) (Fig. 1 B). This result supports the result of Mozumder et al. (2010) and they observed that wider spacing $(20 \mathrm{~cm})$, plants could not cover the inter-row areas and weeds were found to grow vigorously. 
Effect of seed rate: Different seed rates had significant effect on all the parameters studied (Table 3). Plant height, number of leaves/plant and single plant weight decreased with the increasing seed rates. Plant height and number of leaves/plant was found to be the highest in lower seed rate $(30 \mathrm{~kg} / \mathrm{ha})$ and lower in the maximum seed rate $(50 \mathrm{~kg} / \mathrm{ha})$. The maximum single plant weight was also obtained from the lowest seed rate $(2.25 \mathrm{~g} / \mathrm{plant})$ and it was statistically different from other seed rates. Seed rate of $40 \mathrm{~kg} / \mathrm{ha}(2.09 \mathrm{~g} / \mathrm{plant})$ and $50 \mathrm{~kg} / \mathrm{ha}(2.12$ $\mathrm{g} /$ plant) gave statistically identical plant weight. An increase in the seed rate from 30 to $50 \mathrm{~kg} / \mathrm{ha}$, significantly reduced plant height, number of leaves/plant and single plant weight because of an inter-plant competition for nutrients, moisture and light. Number of plants $/ \mathrm{m}^{2}$ and plant weight $/ \mathrm{m}^{2}$ increased with the increasing seed rates (Table 1). The maximum plants $/ \mathrm{m}^{2}$ (548.4) and the highest plant weight $/ \mathrm{m}^{2}(1.11 \mathrm{~kg})$ were observed in the highest seed rate $(50 \mathrm{~kg} / \mathrm{ha})$, while minimum in lower seed rate. These results are in corroborate with the results of Moniruzzaman et al. (2000) and Mozumder et al. (2010).

Table 3. Effect of genotypes, sowing methods and seed rate on yield attributes of coriander for foliage production.

\begin{tabular}{l|c|c|c|c|c}
\hline Treatment & $\begin{array}{c}\text { Plant height } \\
(\mathrm{cm})\end{array}$ & $\begin{array}{c}\text { Leaves/ } \\
\text { plant (no.) }\end{array}$ & $\begin{array}{c}\text { Single plant } \\
\text { weight }(\mathrm{g})\end{array}$ & $\begin{array}{c}\text { Plants/ } \mathrm{m}^{2} \\
(\mathrm{no} .)\end{array}$ & $\begin{array}{c}\text { Plant weight/ } \\
\mathrm{m}^{2}(\mathrm{~kg})\end{array}$ \\
\hline Genotype (CS) & & & & & \\
CS001 & $16.79 \mathrm{c}$ & $6.92 \mathrm{~b}$ & $2.44 \mathrm{~b}$ & $461.9 \mathrm{c}$ & $1.09 \mathrm{~b}$ \\
CS002 & $21.46 \mathrm{~b}$ & $6.15 \mathrm{c}$ & $2.18 \mathrm{c}$ & $431.0 \mathrm{~d}$ & $0.95 \mathrm{c}$ \\
CS003 & $24.77 \mathrm{a}$ & $7.31 \mathrm{a}$ & $2.93 \mathrm{a}$ & $465.9 \mathrm{~b}$ & $1.21 \mathrm{a}$ \\
CS008 & $13.94 \mathrm{~d}$ & $4.70 \mathrm{~d}$ & $1.06 \mathrm{~d}$ & $526.6 \mathrm{a}$ & $0.44 \mathrm{~d}$ \\
Sowing method (P) & 19.24 & $6.73 \mathrm{a}$ & $2.32 \mathrm{a}$ & $463.2 \mathrm{~b}$ & $1.01 \mathrm{a}$ \\
$\mathrm{P}_{1}$ & 19.23 & $5.89 \mathrm{c}$ & $1.98 \mathrm{c}$ & $439.5 \mathrm{c}$ & $0.76 \mathrm{~b}$ \\
$\mathrm{P}_{2}$ & 19.25 & $6.19 \mathrm{~b}$ & $2.14 \mathrm{~b}$ & $511.4 \mathrm{a}$ & $0.99 \mathrm{a}$ \\
$\mathrm{P}_{3}$ & & & & \\
Seed rate (S) & $19.34 \mathrm{a}$ & $6.56 \mathrm{a}$ & $2.25 \mathrm{a}$ & $391.6 \mathrm{c}$ & $0.76 \mathrm{c}$ \\
$\mathrm{S}_{1}$ & $19.22 \mathrm{~b}$ & $6.37 \mathrm{~b}$ & $2.09 \mathrm{~b}$ & $474.1 \mathrm{~b}$ & $0.90 \mathrm{~b}$ \\
$\mathrm{~S}_{2}$ & $19.16 \mathrm{c}$ & $5.88 \mathrm{c}$ & $2.12 \mathrm{~b}$ & $548.4 \mathrm{a}$ & $1.11 \mathrm{a}$ \\
$\mathrm{S}_{3}$ & 3.17 & 3.75 & 5.29 & 3.35 & 6.72 \\
\hline $\mathrm{CV}(\%)$ & & & & & \\
\hline
\end{tabular}

Means showing different letters in a column are significantly different at $5 \%$ level by DMRT.

$\mathrm{P}_{1}=$ Continuous line sowing spaced at $10 \mathrm{~cm}$

$\mathrm{S}_{1}=30 \mathrm{~kg} \mathrm{seed} / \mathrm{ha}$

$\mathrm{P}_{2}=$ Continuous line sowing spaced at $20 \mathrm{~cm}$

$\mathrm{S}_{2}=40 \mathrm{~kg} \mathrm{seed} / \mathrm{ha}$

$\mathrm{P}_{3}=$ Broadcast

$\mathrm{S}_{3}=50 \mathrm{~kg} \mathrm{seed} / \mathrm{ha}$ 

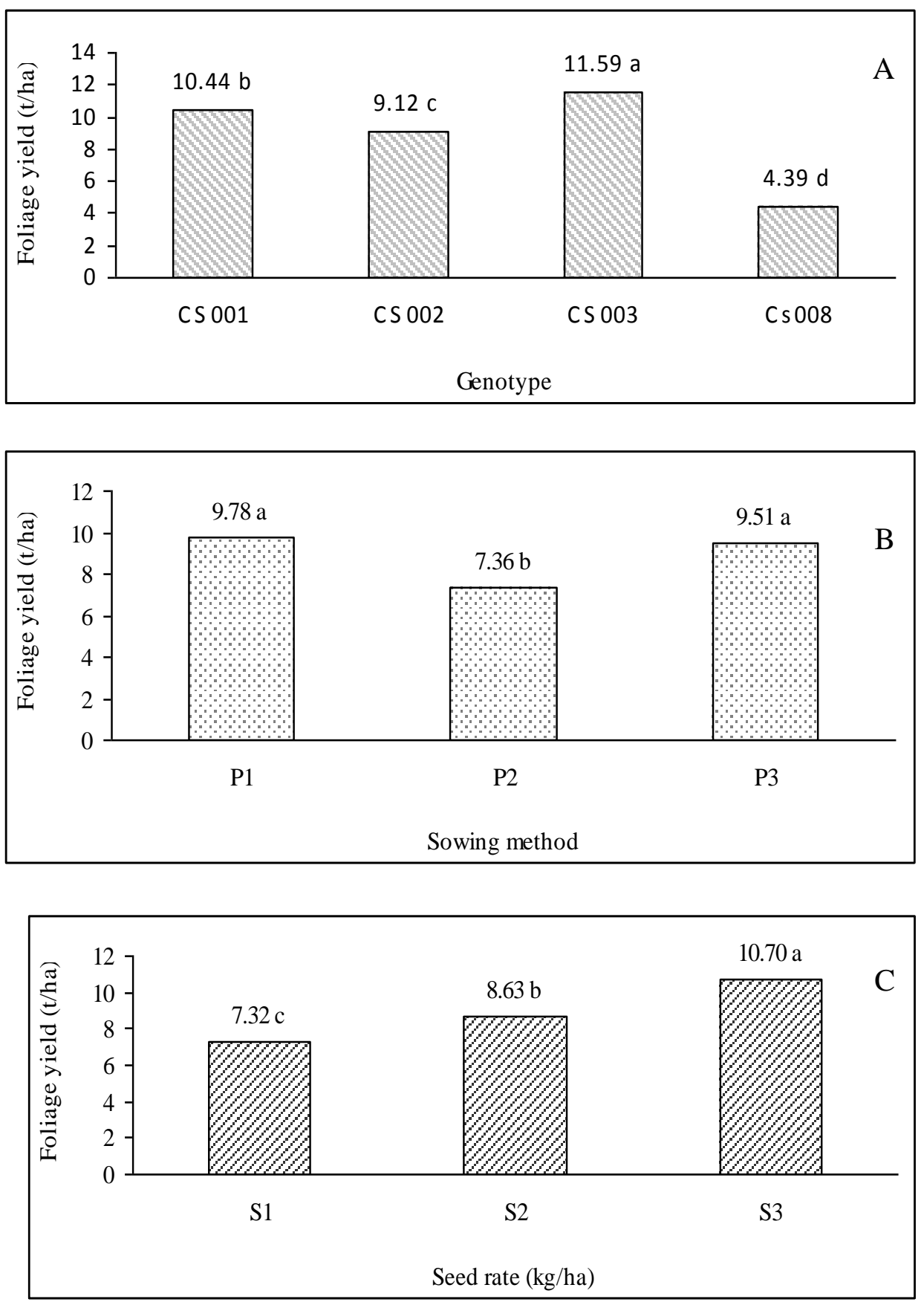

Fig. 1. Foliage yield of coriander as influenced by genotype (A), sowing method (B) and seed rate (C). Means showing different letters placed on the top of the bars were significant at $5 \%$ level by DMRT. 
The Fig. 1C reflected that foliage yield increased with the increase of seed rates. The highest foliage yield was recorded in $50 \mathrm{~kg} \mathrm{seed} / \mathrm{ha}(10.70 \mathrm{t} / \mathrm{ha})$ and the lowest in $30 \mathrm{~kg}$ seed $/ \mathrm{ha}(7.32 \mathrm{t} / \mathrm{ha})$. The highest seed rate gave the highest foliage yield due to increased plants $/ \mathrm{m}^{2}$. The results are in agreement with the findings of Gimson (1985) who reported that the highest foliage yield obtained from $50-55 \mathrm{~kg}$ seed/ha.

Interaction effect of genotype and sowing method: The interaction effect of genotype and sowing method on yield attributes and foliage yield was significant except plant height (Table 4). The highest leaves/plant (7.97) was recorded from genotype CSO03 with continuous line sowing spaced at $10 \mathrm{~cm}$ and it was significantly different from all other treatment combinations. The highest single plant weight ( $3.10 \mathrm{~g} / \mathrm{plant}$ ) was observed from genotype CS003 with line sowing $(10 \mathrm{~cm})$. No significant difference was observed among the interactions of CS008 with three sowing methods in respect of single plant weight. The broadcast method with genotype CS008 gave the highest number of plants $/ \mathrm{m}^{2}$ (579.6). This result corroborates to Abbas et al. (2009) who supported the highest number of plants $/ \mathrm{m}^{2}$ in broadcasting method compared to row spacings. It was evident that number of plants $/ \mathrm{m}^{2}$ was found to be the highest when each genotype interacted with broadcast method. It was found minimum at line sowing spaced at $10 \mathrm{~cm}$ with CS002 and it was statistically similar with CS003 x $\mathrm{P}_{2}$ combination. The maximum of plant weight $/ \mathrm{m}^{2}$ was observed from CSO03 with closer spacing $(1.32 \mathrm{~kg})$, which was at par with the same genotype with broadcast method (1.28 $\mathrm{kg})$, CS001 with closer spacing $(1.21 \mathrm{~kg})$ and CS001 with broadcast method $(1.18 \mathrm{~kg})$. The highest foliage yield $(12.74 \mathrm{t} / \mathrm{ha})$ was recorded from the treatment combination of CS003 $\times \mathrm{P}_{1}$ which was statistically similar with $\mathrm{CS} 003 \times \mathrm{P}_{3}$ combination. The lowest foliage yield (3.86 t/ha) was obtained from CS008 x $\mathrm{P}_{2}$ and it was statistically identical with CS008 $\mathrm{P} \mathrm{P}_{3}$ and CS008 $\times \mathrm{P}_{2}$ combinations. Foliage yield increased upto $230 \%$ in CS003 x $\mathrm{P}_{1}$ compared to CS008 $\times \mathrm{P}_{2}$.

Interaction effect of genotype and seed rate: Foliage yield (t/ha) and other characters studied except plant height were significantly influenced by genotype and seed rate interaction (Table 5). The genotype CS003 with 30 and $40 \mathrm{~kg}$ seed rate/ha and CS001 with $30 \mathrm{~kg} / \mathrm{ha}$ seed rate produced significantly identical leaves/plant. The lower seed rate $(30 \mathrm{~kg} / \mathrm{ha})$ gave the maximum leaves/plant irrespective of genotypes. There was no significant difference between 30 and 40 $\mathrm{kg}$ seed rate/ha irrespective of genotypes except the genotype CS001. The highest single plant weight $(3.18 \mathrm{~g} / \mathrm{plant})$ was produced by CSO03 with $30 \mathrm{~kg}$ seed 
rate/ha. The lowest single plant weight was recorded by genotype CS008 irrespective of seed rates.

The interaction of CS008 and $50 \mathrm{~kg} / \mathrm{ha}$ seed rate produced the highest of plants $/ \mathrm{m}^{2}$ (636.2). It was observed that plants $/ \mathrm{m}^{2}$ was found to be the highest when each genotype interacted with the highest seed rate. The next better result was obtained from all the genotypes irrespective of $40 \mathrm{~kg}$ seed rate/ha. The maximum plant weight $/ \mathrm{m}^{2}$ was obtained by $50 \mathrm{~kg}$ seed rate/ha with CS003 (1.47 $\mathrm{kg}$ ). The maximum foliage yield (14.07 t/ha) was recorded by genotype CS003 with $50 \mathrm{~kg}$ seed rate/ha and it was significantly different from other treatment combinations. The minimum foliage yield (3.80 t/ha) was obtained from CS008 x $\mathrm{S}_{1}$ which was statistically similar with CS008 $\times \mathrm{S}_{2}$ combination $(4.33 \mathrm{t} / \mathrm{ha})$. It was noted that the highest foliage yield was produced from the highest seed rate interacted with each genotype.

Table 4. Interaction effect of genotype and sowing method on yield attributes and foliage yield of coriander.

\begin{tabular}{c|c|c|c|c|c|c}
\hline $\begin{array}{c}\text { Treatment } \\
\text { combination }\end{array}$ & $\begin{array}{c}\text { Plant } \\
\text { height } \\
(\mathrm{cm})\end{array}$ & $\begin{array}{c}\text { Leaves } \\
\text { /plant } \\
(\text { no. })\end{array}$ & $\begin{array}{c}\text { Single } \\
\text { plant } \\
\text { weight }(\mathrm{g})\end{array}$ & $\begin{array}{c}\text { Plants } / \mathrm{m}^{2} \\
(\text { no. })\end{array}$ & $\begin{array}{c}\text { Plant } \\
\text { weight/m } / \mathrm{m}^{2} \\
(\mathrm{~kg})\end{array}$ & $\begin{array}{c}\text { Foliage } \\
\text { yield }(\mathrm{t} / \mathrm{ha})\end{array}$ \\
\hline $\mathrm{CS} 001 \times \mathrm{P}_{1}$ & 16.80 & $7.27 \mathrm{~b}$ & $2.60 \mathrm{~d}$ & $454.4 \mathrm{e}$ & $1.21 \mathrm{ab}$ & $11.65 \mathrm{~b}$ \\
$\mathrm{CS} 001 \times \mathrm{P}_{2}$ & 16.82 & $6.85 \mathrm{c}$ & $2.13 \mathrm{e}$ & $434.7 \mathrm{f}$ & $0.87 \mathrm{~cd}$ & $8.38 \mathrm{~d}$ \\
$\mathrm{CS} 001 \times \mathrm{P}_{3}$ & 16.77 & $6.65 \mathrm{~cd}$ & $2.58 \mathrm{de}$ & $496.7 \mathrm{c}$ & $1.18 \mathrm{ab}$ & $11.29 \mathrm{~b}$ \\
$\mathrm{CS} 002 \times \mathrm{P}_{1}$ & 21.46 & $6.53 \mathrm{~d}$ & $2.47 \mathrm{~d}$ & $426.7 \mathrm{~g}$ & $1.05 \mathrm{bc}$ & $10.07 \mathrm{c}$ \\
$\mathrm{CS} 002 \times \mathrm{P}_{2}$ & 21.45 & $5.75 \mathrm{f}$ & $2.02 \mathrm{e}$ & $408.1 \mathrm{~h}$ & $0.77 \mathrm{~d}$ & $7.36 \mathrm{e}$ \\
$\mathrm{CS} 002 \times \mathrm{P}_{3}$ & 21.48 & $6.17 \mathrm{e}$ & $2.03 \mathrm{e}$ & $458 . .2 \mathrm{e}$ & $1.03 \mathrm{~b}$ & $9.92 \mathrm{c}$ \\
$\mathrm{CS} 003 \times \mathrm{P}_{1}$ & 24.73 & $7.97 \mathrm{a}$ & $3.10 \mathrm{a}$ & $458.2 \mathrm{e}$ & $1.32 \mathrm{a}$ & $12.74 \mathrm{a}$ \\
$\mathrm{CS} 003 \times \mathrm{P}_{2}$ & 24.75 & $6.79 \mathrm{c}$ & $2.82 \mathrm{bc}$ & $428.3 \mathrm{~g}$ & $1.03 \mathrm{bc}$ & $9.83 \mathrm{c}$ \\
$\mathrm{CS} 003 \times \mathrm{P}_{3}$ & 24.82 & $7.17 \mathrm{~b}$ & $2.87 \mathrm{~b}$ & $511.0 \mathrm{~b}$ & $1.28 \mathrm{a}$ & $12.20 \mathrm{ab}$ \\
$\mathrm{CS} 008 \times \mathrm{P}_{1}$ & 13.96 & $5.17 \mathrm{~g}$ & $1.20 \mathrm{f}$ & $513.3 \mathrm{~b}$ & $0.47 \mathrm{e}$ & $4.67 \mathrm{f}$ \\
$\mathrm{CS} 008 \times \mathrm{P}_{2}$ & 13.90 & $4.17 \mathrm{i}$ & $0.96 \mathrm{f}$ & $487.0 \mathrm{~d}$ & $0.38 \mathrm{e}$ & $3.86 \mathrm{f}$ \\
$\mathrm{CS} 008 \times \mathrm{P}_{3}$ & 13.95 & $4.77 \mathrm{~h}$ & $1.10 \mathrm{f}$ & $579.6 \mathrm{a}$ & $0.46 \mathrm{e}$ & $4.65 \mathrm{f}$ \\
\hline $\mathrm{CV}(\%)$ & 3.17 & 3.75 & 5.29 & 3.35 & 6.72 & 4.86 \\
\hline
\end{tabular}

Means showing different letters in a column are significantly different at 5\% level by DMRT.

$\mathrm{P}_{1}=$ Continuous line sowing spaced at $10 \mathrm{~cm}, \mathrm{P}_{2}=$ Continuous line sowing spaced at $20 \mathrm{~cm}, \mathrm{P}_{3}=$ Broadcast. 
Table 5. Interaction effect of genotype and seed rate on yield attributes and foliage yield of coriander.

\begin{tabular}{c|c|c|c|c|c|c}
\hline $\begin{array}{c}\text { Treatment } \\
\text { combination }\end{array}$ & $\begin{array}{c}\text { Plant } \\
\text { height } \\
(\mathrm{cm})\end{array}$ & $\begin{array}{c}\text { Leaves } \\
/ \text { plant } \\
(\text { no. })\end{array}$ & $\begin{array}{c}\text { Single } \\
\text { plant } \mathrm{wt} \\
(\mathrm{g})\end{array}$ & $\begin{array}{c}\text { Plants } / \mathrm{m}^{2} \\
(\mathrm{no} .)\end{array}$ & $\begin{array}{c}\text { Plant } \\
\mathrm{wt} / \mathrm{m}^{2} \\
(\mathrm{~kg})\end{array}$ & $\begin{array}{c}\text { Foliage yield } \\
(\mathrm{t} / \mathrm{ha})\end{array}$ \\
\hline $\mathrm{CS} 001 \times \mathrm{S}_{1}$ & 16.92 & $7.45 \mathrm{a}$ & $2.49 \mathrm{c}$ & $387.2 \mathrm{~h}$ & $0.89 \mathrm{de}$ & $8.54 \mathrm{~g}$ \\
$\mathrm{CS} 001 \times \mathrm{S}_{2}$ & 16.80 & $7.05 \mathrm{~b}$ & $2.37 \mathrm{cde}$ & $471.9 \mathrm{e}$ & $1.06 \mathrm{~cd}$ & $10.14 \mathrm{~d} \mathrm{e}$ \\
$\mathrm{CS} 001 \times \mathrm{S}_{3}$ & 16.67 & $6.27 \mathrm{~cd}$ & $2.44 \mathrm{~cd}$ & $526.7 \mathrm{~b}$ & $1.32 \mathrm{ab}$ & $12.64 \mathrm{~b}$ \\
$\mathrm{CS} 002 \times \mathrm{S}_{1}$ & 21.50 & $6.50 \mathrm{c}$ & $2.23 \mathrm{def}$ & $352.6 \mathrm{i}$ & $0.78 \mathrm{e}$ & $7.45 \mathrm{~h}$ \\
$\mathrm{CS} 002 \times \mathrm{S}_{2}$ & 21.44 & $6.03 \mathrm{de}$ & $2.11 \mathrm{f}$ & $431.6 \mathrm{f}$ & $0.92 \mathrm{de}$ & $8.83 \mathrm{fg}$ \\
$\mathrm{CS} 002 \times \mathrm{S}_{3}$ & 21.45 & $5.91 \mathrm{e}$ & $2.18 \mathrm{ef}$ & $508.9 \mathrm{~d}$ & $1.15 \mathrm{bc}$ & $11.07 \mathrm{~cd}$ \\
$\mathrm{CS} 003 \times \mathrm{S}_{1}$ & 24.98 & $7.47 \mathrm{a}$ & $3.18 \mathrm{a}$ & $400.2 \mathrm{~g}$ & $0.99 \mathrm{~cd}$ & $9.49 \mathrm{ef}$ \\
$\mathrm{CS} 003 \times \mathrm{S}_{2}$ & 24.71 & $7.45 \mathrm{a}$ & $2.84 \mathrm{~b}$ & $475.3 \mathrm{e}$ & $1.17 \mathrm{bc}$ & $11.20 \mathrm{c}$ \\
$\mathrm{CS} 003 \times \mathrm{S}_{3}$ & 24.62 & $7.00 \mathrm{~b}$ & $2.77 \mathrm{~b}$ & $522.0 \mathrm{bc}$ & $1.47 \mathrm{a}$ & $14.07 \mathrm{a}$ \\
$\mathrm{CS} 008 \times \mathrm{S}_{1}$ & 13.98 & $4.93 \mathrm{f}$ & $1.08 \mathrm{~g}$ & $426.2 \mathrm{f}$ & $0.38 \mathrm{f}$ & $3.80 \mathrm{j}$ \\
$\mathrm{CS} 008 \times \mathrm{S}_{2}$ & 13.94 & $4.83 \mathrm{f}$ & $1.03 \mathrm{~g}$ & $517.4 \mathrm{c}$ & $0.43 \mathrm{f}$ & $4.33 \mathrm{ij}$ \\
$\mathrm{CS} 008 \times \mathrm{S}_{3}$ & 13.88 & $4.33 \mathrm{~g}$ & $1.06 \mathrm{~g}$ & $636.2 \mathrm{a}$ & $0.50 \mathrm{f}$ & $5.03 \mathrm{i}$ \\
\hline $\mathrm{CV}(\%)$ & 3.17 & 3.75 & 5.29 & 3.35 & 6.72 & 4.86 \\
\hline
\end{tabular}

Means showing different letters in a column are significantly different at $5 \%$ level by DMRT. $\mathrm{S}_{1}=30 \mathrm{~kg} / \mathrm{ha}, \mathrm{S}_{2}=40 \mathrm{~kg} / \mathrm{ha}, \mathrm{S}_{3}=50 \mathrm{~kg} / \mathrm{ha}$

Interaction effect of sowing method and seed rate: Interaction of sowing method and seed rate with the genotype was significant in respect of all parameters except plant height (Table 6). The maximum number leaves/plant (7.05) was recorded from $P_{2} \times S_{1}$ closely followed by $P_{2} \times S_{2}$ combinations and minimum from $P_{3} \times S_{3}$ combination which was at par with $P_{1} \times S_{1}$ and $P_{3} \times S_{3}$ combinations. This is in accordance with Soomro et al. (2009). Higher single plant weight $(2.37 \mathrm{~g} / \mathrm{plant})$ was produced by $\mathrm{P}_{1} \times \mathrm{S}_{1}$ combination which was statistically identical with $\mathrm{P}_{1} \times \mathrm{S}_{2}, \mathrm{P}_{1} \times \mathrm{S}_{3}$ and $\mathrm{P}_{3} \times \mathrm{S}_{1}$ combinations and the lowest from $\mathrm{P}_{2} \times \mathrm{S}_{2}$ combination. The maximum number of plants $/ \mathrm{m}^{2}$ was recorded from $\mathrm{P}_{3} \times \mathrm{S}_{3}$ combination and the minimum from $\mathrm{P}_{1} \times \mathrm{S}_{1}$ combination. Line sowing $(10 \mathrm{~cm})$ coupled with $50 \mathrm{~kg} / \mathrm{ha}$ seed rate produced the maximum plant weight $/ \mathrm{m}^{2}(1.22 \mathrm{~kg})$ that was closely followed by broadcast method of the same seed rate $(1.19 \mathrm{~kg} / \mathrm{ha})$. The lowest plant weight $/ \mathrm{m}^{2}$ was obtained from 20 $\mathrm{cm}$ apart line sowing with $30 \mathrm{~kg} / \mathrm{ha}$ seed rate. This is in perfect agreement with the report of Mozumder et al. (2010). The maximum foliage yield (11.81t/ha) was obtained from $\mathrm{P}_{1} \mathrm{~S}_{3}$ which was closely followed by that of $\mathrm{P}_{3} \mathrm{~S}_{3}$. Both the treatments gave similar yield due to higher yield attributes. 
Table 6. Interaction effect of sowing method and seed rate on yield attributes and foliage yield of coriander

\begin{tabular}{c|c|c|c|c|c|c}
\hline $\begin{array}{c}\text { Treatment } \\
\text { combination }\end{array}$ & $\begin{array}{c}\text { Plant } \\
\text { height } \\
(\mathrm{cm})\end{array}$ & $\begin{array}{c}\text { Leaves } \\
/ \text { plant } \\
(\text { no. })\end{array}$ & $\begin{array}{c}\text { Single } \\
\text { plant wt } \\
(\mathrm{g})\end{array}$ & $\begin{array}{c}\text { Plants } / \mathrm{m}^{2} \\
(\mathrm{no} .)\end{array}$ & $\begin{array}{c}\text { Plant } \\
\mathrm{wt} / \mathrm{m}^{2} \\
(\mathrm{~kg})\end{array}$ & $\begin{array}{c}\text { Foliage yield } \\
(\mathrm{t} / \mathrm{ha})\end{array}$ \\
\hline $\mathrm{P}_{1} \times \mathrm{S}_{1}$ & 19.37 & $6.43 \mathrm{~b}$ & $2.37 \mathrm{a}$ & $377.1 \mathrm{f}$ & $0.83 \mathrm{bcd}$ & $8.03 \mathrm{c}$ \\
$\mathrm{P}_{1} \times \mathrm{S}_{2}$ & 19.18 & $6.39 \mathrm{~b}$ & $2.26 \mathrm{ab}$ & $463.0 \mathrm{~d}$ & $0.98 \mathrm{~b}$ & $9.50 \mathrm{~b}$ \\
$\mathrm{P}_{1} \times \mathrm{S}_{3}$ & 19.16 & $5.75 \mathrm{c}$ & $2.34 \mathrm{a}$ & $549.4 \mathrm{~b}$ & $1.22 \mathrm{a}$ & $11.81 \mathrm{a}$ \\
$\mathrm{P}_{2} \times \mathrm{S}_{1}$ & 19.34 & $7.05 \mathrm{a}$ & $2.13 \mathrm{bc}$ & $360.8 \mathrm{~g}$ & $0.64 \mathrm{e}$ & $6.14 \mathrm{e}$ \\
$\mathrm{P}_{2} \times \mathrm{S}_{2}$ & 19.23 & $6.88 \mathrm{a}$ & $1.88 \mathrm{~d}$ & $439.2 \mathrm{e}$ & $0.74 \mathrm{de}$ & $7.11 \mathrm{~d}$ \\
$\mathrm{P}_{2} \times \mathrm{S}_{3}$ & 19.13 & $6.27 \mathrm{~b}$ & $1.94 \mathrm{~cd}$ & $518.7 \mathrm{c}$ & $0.92 \mathrm{bc}$ & $8.83 \mathrm{~b}$ \\
$\mathrm{P}_{3} \times \mathrm{S}_{1}$ & 19.33 & $6.21 \mathrm{~b}$ & $2.24 \mathrm{ab}$ & $436.8 \mathrm{e}$ & $0.81 \mathrm{~cd}$ & $7.80 \mathrm{~cd}$ \\
$\mathrm{P}_{3} \times \mathrm{S}_{2}$ & 19.25 & $5.84 \mathrm{c}$ & $2.12 \mathrm{bc}$ & $520.0 \mathrm{c}$ & $0.96 \mathrm{bc}$ & $9.27 \mathrm{~b}$ \\
$\mathrm{P}_{3} \times \mathrm{S}_{3}$ & 19.18 & $5.62 \mathrm{c}$ & $2.07 \mathrm{bcd}$ & $577.3 \mathrm{a}$ & $1.19 \mathrm{a}$ & 11.47 \\
\hline $\mathrm{CV}(\%)$ & 3.17 & 3.75 & 5.29 & 3.35 & 6.72 & 4.86 \\
\hline
\end{tabular}

Means showing different letters in a column are significantly different at $5 \%$ level by DMRT. $\mathrm{P}_{1}=$ Continuous line sowing spaced at $10 \mathrm{~cm}, \mathrm{P}_{2}=$ Continuous line sowing spaced at $20 \mathrm{~cm}, \mathrm{P}_{3}=$ Broadcast; $\mathrm{S}_{1}=30 \mathrm{~kg} / \mathrm{ha}, \mathrm{S}_{2}=40 \mathrm{~kg} / \mathrm{ha}, \mathrm{S}_{3}=50 \mathrm{~kg} / \mathrm{ha}$.

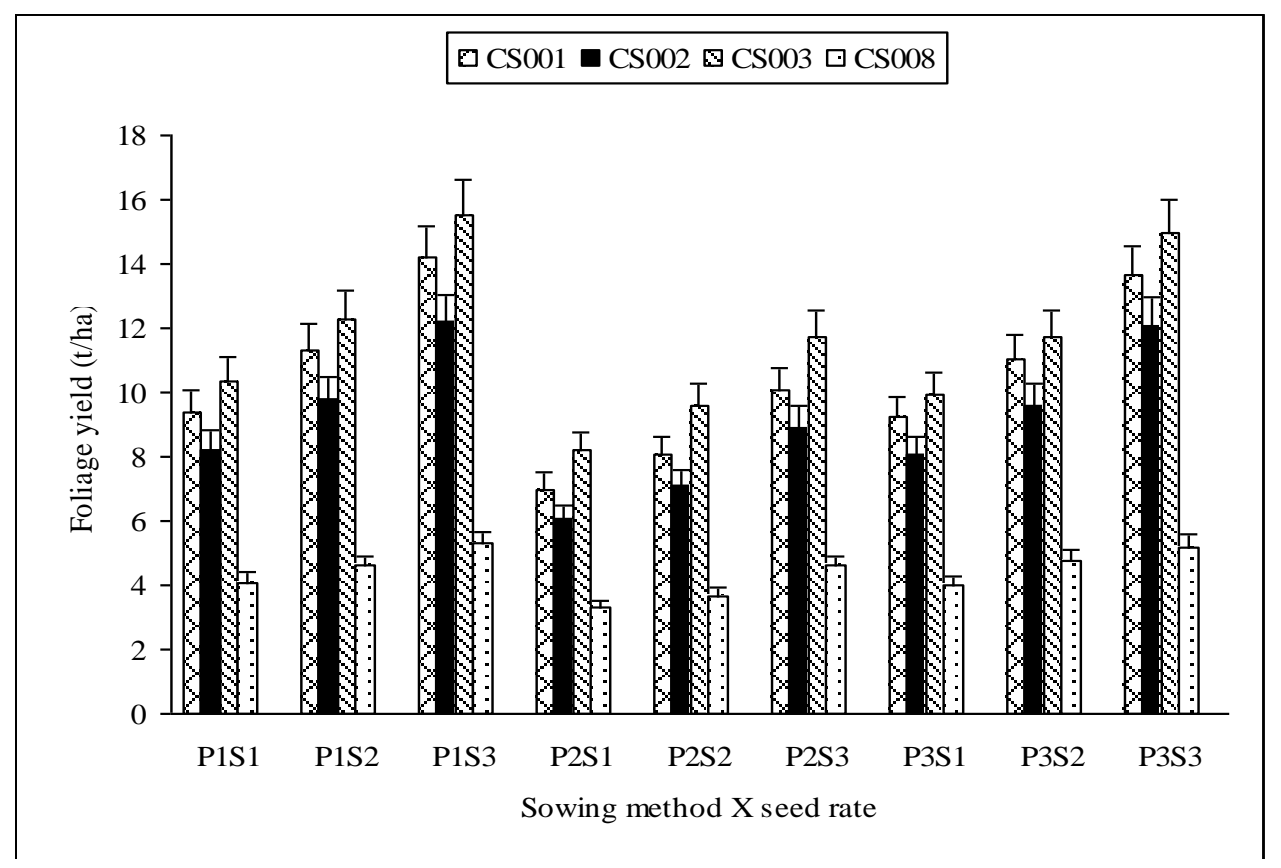

Fig. 2. Interaction effect of genotype, sowing method and seed rate on foliage yield. Bars showing SE \pm . 
Interaction of sowing method and seed rate with the genotype: The data have been explained on the basis of individual genotypic responses (Fig. 2). Interaction effects of genotype, sowing method and seed rate ( $\mathrm{G} \times \mathrm{P} \times \mathrm{S})$ showed significant influence on foliage yield of coriander (Fig. 2). The interaction of closer sowing $(10 \mathrm{~cm})$ with the highest seed rate $(50 \mathrm{~kg} / \mathrm{ha})$, in each genotype except CS008 produced the highest foliage yield which was closely followed by the interaction of broadcast method with the same seed rate. In all genotypes closer sowing coupled with lower seed rate $(30 \mathrm{~kg} / \mathrm{ha})$ gave foliage yield which was identical with that of the same sowing with broadcast method. Interaction of closer sowing and medium seed rate (40 kg/ha) produced foliage yield which was at par with the same seed rate with broadcast method in four genotypes. But broadcast sowing with lower seed rate gave higher foliage yield than $20 \mathrm{~cm}$ line sowing with $40 \mathrm{~kg}$ seed rate/ha in every genotype.. The $20 \mathrm{~cm}$ line sowing coupled with lower seed rate gave the lowest foliage yield in all genotypes. There was little variation in all interactions in CSO08; however, the combination of closer sowing and the highest seed rate $(50 \mathrm{~kg} / \mathrm{ha})$ as well as broadcast method and the same seed rate produced the maximum foliage yield.

\section{Conclusion}

It might be concluded that the seed rate of $50 \mathrm{~kg} / \mathrm{ha}$ coupled with either continuous line sowing $(10 \mathrm{~cm}$ spaced) or broadcast method with the genotype CS003 gave the highest foliage production in coriander.

\section{References}

Abbas, G., M. A. Ali, G. Abbas, M. Azam and I. Hussain. 2009. Impact of planting methods of wheat grain yield and yield contributing characters. The J. Animal \& Plant Sci. 19(1): 30-33.

Ayub, M., M. A. Nadeem, A. Tanveer, M. Tahir, M. T. Y. Saqib and R. Nawaz. 2008. Effect of different sowing methods and times on the growth and yield of fennel (Foeniculum vulgare Mill.). Pakistan J. Bot. 40 (1); 259-264.

Gimson, P. 1985. Coriander. Oxfam veg. project full of Eastern promise. Grower 103: 21- 22.

Janardhonan, M. and J. E. Thoppil. 2004. Herb and Spice Essential Oils. Discovery Publishing House, New Delhi-110002. Pp. 40-42.

Moniruzzaman, M. S. M. M. Rahman and S. N. Mozumder. 2000. Effect of seed rate and shade on false coriander (Eryngium foetidum L) production in the hilly area. Bangladesh Hort. 28 (1 \& 2): 34-38.

Mozumder, S. N., M. Moniruzzaman, S. M. M. Rahman, P. C. Sarker and S. M. Faisal. 2010. Influence of seed rate and method of sowing on the performance of Bilatidhonia (Eryngium foetidum L.). Bangladesh J. Agril. Res. 35 (1): 227-234.

Soomro, U. A., M. U. R. E. A. Odhano, S. Gul, A. Q. Tareen. 2009. Effect of sowing method and seed rate on growth and yield of wheat. World J. Agril. Sci. 5 (2): 159-162. 